\title{
ANALYSIS OF QOS TREE FOR MHP SERVICES IN IP NETWORKS IN FRAGILE ENVIRONMENTS INCENTIVE OPNET
}

\author{
Rastislav KOKOŠKA ${ }^{*}$, Janka HANDRIKOVÁ ${ }^{* *}$, Ján VALISKA* \\ * Department of Electronics and Multimedia Communications, Faculty of Electrical Engineering and Informatics, \\ Technical University of Košice, Letná 9, 04200 Košice, Slovak Republic, e-mail: rastko@pobox.sk, jan.valiska@tuke.sk \\ ${ }^{* *}$ Department of Informatics, Armed Forces Academy of General Milan Rastislav Stefánik, Demänová 393, \\ 03106 Liptovský Mikuláš 6, Slovak Republic, e-mail: janka.handrikova@gmail.com
}

\begin{abstract}
The objective of this article is to point at the analysis of QoS (quality of services) stream for MHP services in unstable IP networks in simulated environment of the Modeller. An overview of QoS, their features and ways of implementations are outlined. The offer of quality of services gets broad extension in IPTV services for communication with the Internet, its availability, broadband, speed. The simulating software Opnet Modeller is used to simulate QoS parameters for transfering real video files in unstable network. $3 D$ video files in standard and high definition are used to compare time delay for each video transfer.
\end{abstract}

Keywords: internet protocol television, quality of services, multimedia home platform, delay variation - jitter, packet loss, integrated services, differentiated services

\section{INTRODUCTION}

It is a trend of the period for network designers to build up so called multiservice networks able to transfer all types of communication - voice, data and video with help of packet architecture. The demand of wider and wider band broadness is unceasing, and recently it has been intensified. However, the higher demand of broader band can cause problems with quality, mainly degradation of a time-sensitive type of network operation, like voice is. Voice packets do not have the same advantages as data ones as for the re-sending in case of packet loss during transfer [1].

\section{QUALITY OF SERVICES}

Quality of services (QoS) is ability to provide different priorities for different applications, users, data streams or ability to guarantee certain figure for data stream. For example, required speed of bits, delay, and probability of throwing away packets or error-rate of bits can be guaranteed. Guarantee of quality of services can be important in case the network capacity is not sufficient, especially for multimedia applications streaming in real time, like for example voice transfer through IP (VoIP), on-line games, and IPTV, because these often require fixed transmission speed, and are sensitive to delay, like in networks where capacity is determined by source, for example in cellular data communication. QoS is required in networks without overload [2].

QoS functions provide better and more predictable network services so that: they deal with and manage network overload by forming network operation and they set network operation priority across network.

\subsection{Architecture of QoS}

Concrete elements of QoS architecture depend on the type of transferred information: voice, data or video. For VoIP, QoS defines limitations specific for voice transfer like delay, delay variation or jitter, packet loss, and also echo. [1].

Among the representative metrics of quality of services in computer networks are listed:

1. end delay - period between sending a packet from a source and its delivery to the defined receiver

2. jitter - difference between intervals among the received packets

3. packet loss - ratio of the received and sent packets in a time unit

4. band bandwidth - transfer capacity which is related to load carrying capacity (the amount of successfully transferred data in a time unit) [3].

\subsection{Models of QoS provision}

According to IETF (Internet Engineering Task Force), the solution of reaching higher level of service brings several ways of support. Specifically, it is the following architectures ensuring QoS in the networks[3]:

1. Integrated Services, (IntServ)

2. Differentiated Services, (DiffServ)

3. Multi-Protocol Label Switching (MPLS)

4. Subnet Bandwidth Management [4].

\subsubsection{Integrated services}

Model of integrated services (IntServ) tries to keep the guaranteed level of service for selected services on the whole path of transfer. The application requires from the network to ensure certain level of transfer needed for its correct operation. The application has to know what is the generated stream characteristics, and signal to the nodes on the whole path of transfer [4].

IntServ Model supports two different types of services: service with controlled load - to ensure reliable transfer between two points, and guaranteed service - for guaranteed maximum delay during transfer within the band given [4]. 


\subsubsection{Differentiated services}

Differentiated Services (DiffServ) represent a method, which, with help of a set of classification tools and mechanisms of work with fronts, provides broad possibilities of quality of service via data transfer in network provision. This method is based on the classification of different types of packets crossing network by limit routers. Different streams can be classified according to network address, protocol, entry port. It is also possible to classify different streams with the help of basic or extended access lists. Then they are categorised.

To each class a DiffServ value (DSCP) is bound set. In the core of the network, packets are forwarded again on the basis of defined behaviour of network nodes towards the stream with the relevant SCP value. As neither of the methods! (intServ or DiffServ) offers a complex solution, a combination of these two methods is used. The latest trend in quality service provision is simplification and automation with regard to simplicity and ability to ensure guarantee of service quality in IP networks. Technologies providing quality of service offer a number of possibilities, and can be used for setting up really sophisticated networks [4].

\section{CONFIGURATION OF A SIMULATED NETWORK AND INTERCONNECTION OF OBJECTS}

The proposed network uses SITL interface, which allows displaying a 3D stream video on the receiving side. The simulation is completed by a video server and applications which according to setting up load wireless transfer. In Fig.1, a scheme of simulated network is depicted.

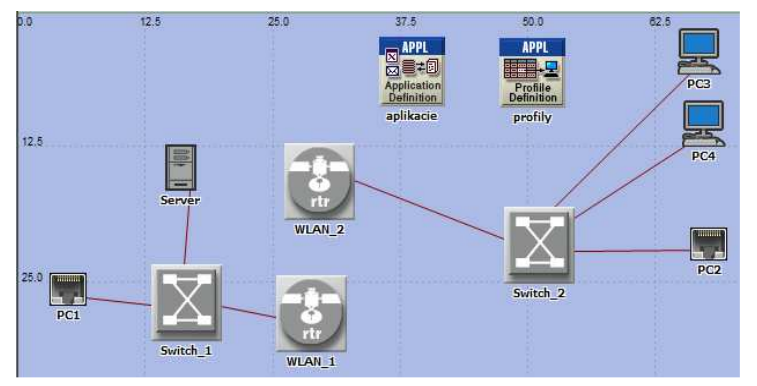

Fig. 1 A proposal of simulated network

In Fig. 1, the network is composed of two SITL interfaces (PC1 a PC2), work stations (PC3 a PC4), switches (Switch 1 a Switch 2), wireless routers (WLAN_1 a WLAN_ 2), video server and objects for applications and profiles setting up. A real computer, in which VLC program is on, is connected to SITL PC1 interface.

The VLC program is a 2.0 .5 version. PC1 streams 3D video with the help of HTTP protocol onto the second real computer, which is connected to SITL PC2 interface.PC2receives the streamed 3D video also with the help of VLC program.

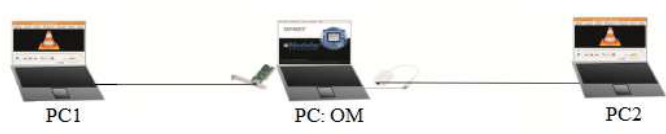

Fig. 2 Real interconnection of computers

In the SITL module, it is important to set up network card. They are the network cards of the computer on which Opnet (Modeler) is running. As notebooks have one network card only, it is necessary to buy the second USB network card. For the attribute Incoming Packet Filter String, it is necessary to induct MAC address of the network card to the preset value arp or ip by the command src, and following the MAC address in the form $\mathrm{XX}: \mathrm{XX}: \mathrm{XX}: \mathrm{XX}: \mathrm{XX}: \mathrm{XX}$. For each interface, it is the MAC address of the computer to which the computer is connected. Setting up of filter provides transfer of packets from the corresponding MAC address to simulation [8]. The sample of setting is in Fig. 3

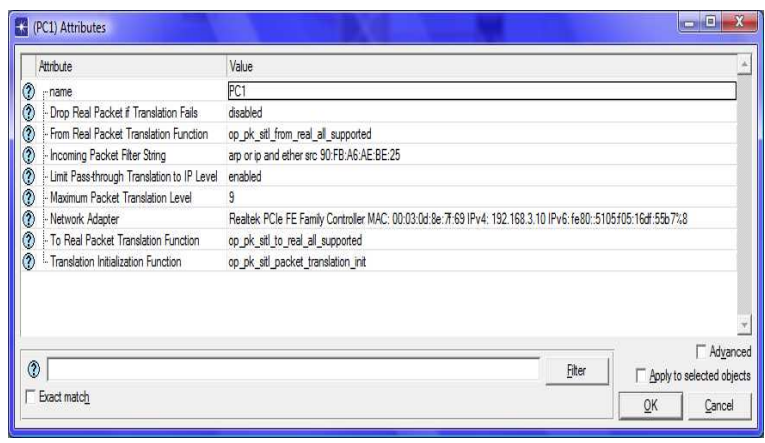

Fig. 3 Setting of attributes for SITL module

With WLAN modules, it is important to set the function Access Point Functionality, where for WLAN_1 this function is allowed, for WLAN 2 prohibited. It is necessary, naturally, to set IP Routing Parameters, i.e. IP addresses of interfaces, and routing protocols according to the table. For WLAN modules, it is possible to change, e.g. speed of transfer, topology of transfer, or buffer.

At the beginning, we define the required number of applications in the attribute Number of Rows. We select the required applications and define the name for each of them. It is necessary to set a profile for these applications. After setting up the applications, we select a number of profiles, in which the selected applications will be located. After defining the name of the profile, we can set time of operation, time of execution, time of repetition, eventually, number of repetitions, and other attributes.

Apart from the assignation of the IP address to the server, it is necessary to allow the application profile support function (Fig. 4), where we select supported profiles pre-set before. 
Table 1 Devices configuration

\begin{tabular}{|c|c|c|c|c|}
\hline Device & Interface & IP address & $\begin{array}{c}\text { Mask of } \\
\text { sub } \\
\text { network }\end{array}$ & $\begin{array}{c}\text { Preset } \\
\text { port }\end{array}$ \\
\hline PC1 & network card & 192.168.3.11 & $\begin{array}{c}255.255 .255 \\
0\end{array}$ & $\begin{array}{c}192.168 . \\
3.1\end{array}$ \\
\hline PC2 & network card & 192.168.1.11 & $\begin{array}{c}255.255 .255 . \\
0\end{array}$ & $\begin{array}{c}192.168 . \\
1.1\end{array}$ \\
\hline PC3 & network card & 192.168.1.12 & $\begin{array}{c}255.255 .255 \\
0\end{array}$ & - \\
\hline PC4 & network card & 192.168.1.13 & $\begin{array}{c}255.255 .255 . \\
0\end{array}$ & - \\
\hline \multirow{2}{*}{ PC:OM } & $\begin{array}{c}\text { built-in } \\
\text { network card }\end{array}$ & 192.168.3.10 & $\begin{array}{c}255.255 .255 . \\
0\end{array}$ & - \\
\hline & $\begin{array}{l}\text { USB network } \\
\text { card }\end{array}$ & 192.168.1.10 & $\begin{array}{c}255.255 .255 . \\
0\end{array}$ & - \\
\hline \multirow{2}{*}{$\begin{array}{l}\text { WLAN } \\
-1\end{array}$} & Ethernet port & 192.168.3.1 & $\begin{array}{c}255.255 .255 . \\
0\end{array}$ & - \\
\hline & $\begin{array}{c}\text { WLAN } \\
\text { interface }\end{array}$ & 192.168.2.2 & $\begin{array}{c}255.255 .255 . \\
0\end{array}$ & - \\
\hline \multirow{2}{*}{$\begin{array}{l}\text { WLAN } \\
\quad 2\end{array}$} & Ethernet port & 192.168.1.1 & $\begin{array}{c}255.255 .255 . \\
0 \\
\end{array}$ & - \\
\hline & $\begin{array}{c}\text { WLAN } \\
\text { interface }\end{array}$ & 192.168.2.1 & $\begin{array}{c}255.255 .255 . \\
0\end{array}$ & - \\
\hline Server & Ethernet port & $\begin{array}{c}192.168 .3 .10 \\
0\end{array}$ & $\begin{array}{c}255.255 .255 \\
0\end{array}$ & - \\
\hline
\end{tabular}

In the proposed simulation, we have two work stations marked as PC3 and PC4. On each of the work stations it is necessary to set IP addresses. Similarly to the server setting, it is necessary to allow support of the created application profiles. Number of work stations is optional. With bigger number of stations which will receive packets from server, the load of network will be higher. With regard to the number of applications and possibilities of network configuration, it is possible to work with different variants.

DES are parameters of simulation which must be set before start of the operation itself. In our case, we must not forget to set the figure Real-time execution ration on the Fig.1. It will be set in the window Configure/Run DES selecting Execution $\rightarrow$ Advanced $\rightarrow$ Kernel preferences in the line Real-time execution ratio on the Fig. 1.

The length of simulation will be set adequately to the length of the streamed 3D video. Within the total time of the simulation duration, several seconds needed to start video stream in $\mathrm{PC1}$, and confirmation of reception in PC2 will be included.

The last step before start of the simulation is selection of statistics which we want to monitor during the simulation, and compare later. After clicking the right mouse button on the desktop Opnet Modeller, we will select the option, where we choose the required statistics.

\subsection{Results of transfer simulation of $3 D$ contents in graphs.}

Each 3D video was of a different quality of picture, specifically $360 \mathrm{p}, 720 \mathrm{p}$ and $1080 \mathrm{p}$. In the simulation scenarios we were comparing the network behaviour at different qualities of video contents, with additional loading with the help of applications video conference, picture browsing, database, FTP, and email.

Each genre was in three different qualities, as we can notice in the overview table Tab. 2. All the samples are in MPEG4/AVC format.

Table 2 Parameters of transferred 3D sequences

\begin{tabular}{|c|c|c|c|c|c|c|}
\hline \multirow[b]{2}{*}{$\begin{array}{l}\text { Name 3D } \\
\text { videa. }\end{array}$} & \multirow[b]{2}{*}{$\begin{array}{l}\text { resolution } \\
\text { (Format } \\
\text { MPEG4/AVC) }\end{array}$} & \multicolumn{2}{|c|}{1 image } & \multicolumn{2}{|c|}{$\mathrm{P}$ image } & \multirow[b]{2}{*}{$\begin{array}{l}\text { Length } \\
\text { sequences } \\
\text { (min.) }\end{array}$} \\
\hline & & $\begin{array}{l}\text { Max.size } \\
(\mathrm{kB})\end{array}$ & $\begin{array}{l}\text { Average } \\
\text { size (kB) }\end{array}$ & $\begin{array}{c}\text { Max.size } \\
(\mathrm{kB})\end{array}$ & $\begin{array}{l}\text { Average } \\
\text { size (kB) }\end{array}$ & \\
\hline \multirow{3}{*}{$\begin{array}{l}\text { Avatar } \\
\text { (action) }\end{array}$} & $1280 \times 266$ & 18,83 & 4,974 & 18,545 & 1,214 & 2:09 \\
\hline & $1280 \times 266$ & 37,804 & 15,766 & 109,162 & 6,929 & $2: 09$ \\
\hline & $1920 \times 400$ & 66,618 & 28,574 & 198,499 & 11,905 & 2:09 \\
\hline \multirow{3}{*}{$\begin{array}{r}\text { Ice Age } 4 \\
\text { (animal) }\end{array}$} & $640 \times 360$ & 39,372 & 12,953 & 9,639 & 2,429 & $2: 18$ \\
\hline & $1280 \times 720$ & 124,553 & 39,867 & 33,414 & 8,8 & 2:18 \\
\hline & $1920 \times 1080$ & 232,363 & 74,778 & 74,26 & 17,64 & $2: 18$ \\
\hline
\end{tabular}

During the 3D video sequences transfer, we were monitoring load carrying capacity, WLAN parameters of transfer, number of received and sent packets by SITL module, time delay of $3 \mathrm{D}$ video during the whole transfer through WLAN.

First graph of the tested 3D video sequence Avatar shows time delay at different quality of the transferred video. The results are depicted in Fig. 5, where it is seen that delay is higher at higher quality of the transferred video. Top figures reach 0.045 second.

Fig. 4 Figure caption 


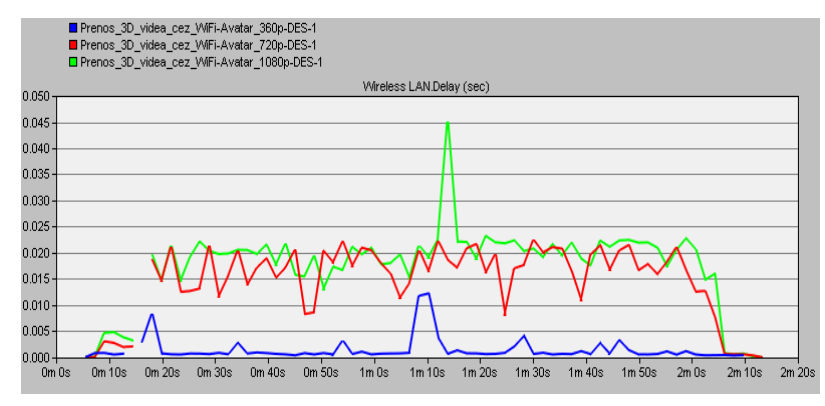

Fig. 5 Time delay - Avatar

Testing of 3D animated sequence Ice Age was run under the same conditions as the previous sequence. In Fig.6 and Fig.7, time delay and load carrying capacity at different video quality are compared.

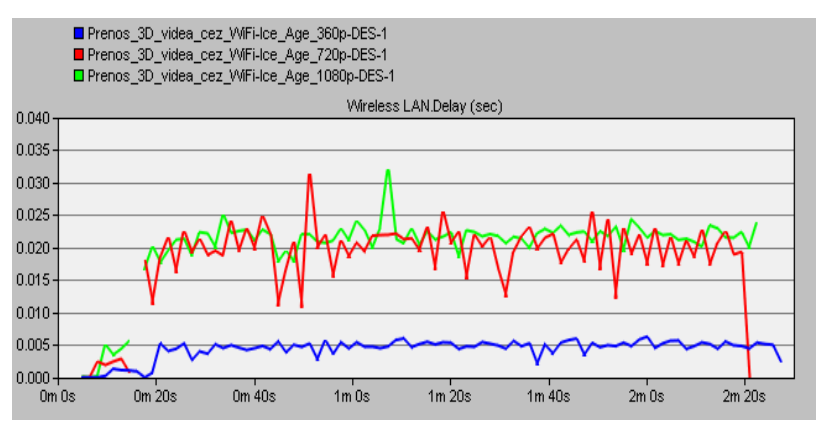

Fig. 6 Time delay - Ice Age

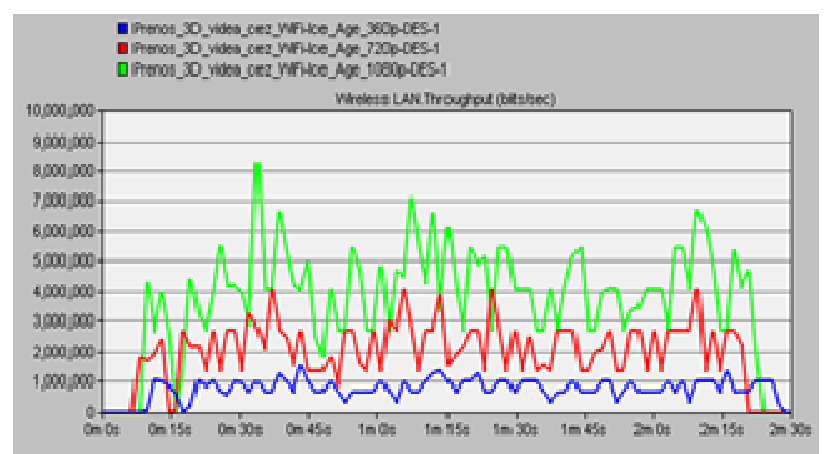

Fig. 7 Load carrying capacity - Ice Age

\section{CONCLUSIONS}

In this article, we wanted to point at the analysis of QoS stream for MHP services in unstable IP networks. The way of quality of services implementation, and its qualities was described. Quality of services is possible to realise in simulating program Opnet (Modeler), which enables modelling, analysis, and network configuration.

From the results of the analysis we can say the higher video quality is qoing to transfer the (higher) time delay will be achieved and there is minimal difference between transfer high definition video in $720 p$ mode and $1080 p$ mode, but significant difference in transferring standard resolution or high resolution video.

\section{ACKNOWLEDGMENT}

This work was supported by the Slovak Cultural and Educational Grant Agency under contract No. 010TUKE$4 / 2012$ and and by the Scientific Grant Agency of the Ministry of Education, science, research and sport of the Slovak Republic under the contract No. $1 / 0563 / 13$

\section{REFERENCES}

[1] SMITKA, P.: Architecture design in IP telephony, http://diplomovka.sme.sk/praca/3224/qosarchitecture-design-in-ip-telephony.php,

ZU, Fakulta riadenia a informatiky, Žilina, 2007.

[2] Quality of services, http://sk.wikipedia.org/wiki/ QoS.

[3] ZAPLETAL, L.: Simulace modelu QoS v prostredí Opnet IT Guru, Fakulta elektrotechniky a komunikačných technológii ústav telekomunikácií, Brno, 2008.

[4] MAJERSKÝ, M.: Simulačný model siete Metro ethernet s MPLS chrbticovou sietou v Opnet Modeler, Žilinská univerzita, Žilina, 2010.

[5] BOŽIK, M: Simulácia prenosu 3D videotokov pomocou programu Opnet Modeler, (Diplomová práca) Technická univerzita v Košiciach, Fakulta elektrotechniky a informatiky, Košice, 2013.

[6] ZEMAN, O.: Modelování sítových aplikací a měření provozu v prostředí Opnet, Vysoké učení technické v Brně, Brno, pp. 2-6, 2006.

[7] Opnet Technologies, Inc., Opnet Modeler Documentation set., 2008.

[8] SENDREI, L.: H.264 Video prenos vo WLAN v prostredí Opnet Modeler, Technická univerzita $\mathrm{v}$ Košiciach, Fakulta elektrotechniky a informatiky, Košice, 2012.

Received September 6, 2013, accepted February 13, 2014

\section{BIOGRAPHIES}

Rastislav Kokoška was born on 5.11.1978 in Prešov. In 2003, he graduated (M.Sc.) from Technical University in Košice, Slovakia. He worked at Samsung Electronics Slovakia in Galanta as an engineer for testing circuit boards PBA. He is studying at doctoral studies in the external form at the Department of Electronics and Multimedia Communications, Faculty of Electrical Engineering and Computer Science at the Technical University in Košice. His scientific research focuses on modelling quality transmission of video data stream Internet $\mathrm{TV}$ on an unstable network. 
Janka Handriková was born on 10.8.1975 in Liptovský Mikuláš. She received her M.Sc. degree in Technical University of Košice. She graduated from Department of Computers and Informatics from Technical University of Košice in May 1998. She is a PhD. student in Department of Informatics, Armed Forces Academy of General Milan Rastislav Štefánik, Liptovský Mikuláš, since september 2012. Her current research interests include image processing, design of database systems for face recognition systems in video sequences, object tracking and Bayesian filtering.
Ján Valiska was born on 14.10.1986 in Michalovce. He received his M.Sc. degree in Technical University of Košice. He graduated from Department of Electronics and Multimedia Communications, from Faculty of Electrical Engineering and Informatics in May 2011. He is a PhD. Student in Department of Electronics and Multimedia Communications at the same university since September 2011. His current research interests include image processing, object tracking, digital television systems and satellite communications. 